\title{
РОД STREPTIS (TRIPLESIIDAE, ВRACHIOPODA) ИЗ ОРДОВИКА И СИЛУРА ЭСТОНИИ
}

В ходе изучения брахиопод пограничных отложений ордовика и силура Северной Прибалтики внимание автора привлекали стратиграфическое распространение и фациальная приуроченность представителей рода Streptis. Этот род триплесидных брахиопод известен лишь пятью видами, из которых три вида - S. undifera, S. altosinuata и S. grayii встречаются также в верхнем ордовике и нижнем силуре Прибалтики. В составе брахиопод ордовика и силура рассматриваемого региона Streptis является одним из немногих родов общих для обоих систем. Из отмеченных трех видов наибольшее внимание стратиграфов заслужил ордовикский вид $S$. undifera. В региональной стратиграфической схеме Прибалтики он принят одним из характерных видов для поркуниского горизонта. Накопленный новый материал по роду Streptis представляет еще интерес с точки зрения строения раковины, особенно по виду $S$. undifera, описанного до сих пор по немногочисленным экземплярам.

В Северной Эстонии родовой состав брахиопод поркуниского горизонта отличается довольно четко от брахиоподовых ассоциаций, выделенных в пределах последнего горизонта ордовика - горизонта $5 b$ в районе Осло (Brenchley, Cocks, 1982) и горизонта Хирнант в Северном Уэльсе (Brenchley, Cullen, 1984). В этих районах только относительно глубоководная ассоциация Onniella, формирование которой началось в дохирнантиевом времени, содержит представителей родов, общих с поркуниским горизонтом Северной Эстонии (Reushella, Oxoplecia, Platystrophia, Leptaena и др.). В последнем районе поркуниский горизонт, в том числе породы, содержащие $S$. undifera относятся к отмельной фации. Они представлены биогермным комплексом пород (Пылма, 1982). Распространение этого вида в Норвегии может быть связано с мелководными отложениями (5a, водорослевые, палеопорелловые известняки), как, возможно, и вид S. monilifera из верхнего ордовнка Ирландии (в известняках Портрейн и Килдэр, в формации Килли Бридж; Wright, 1964, 1968; Mitchell, 1977). Предполагая определенную зависимость характера внешней скульптуры от фациальных условий можно допускать, что ирландский вид S. monilifera pacпространялся в более глубоководных условиях, чем балтоскандийский вид. Силурийские стрептисы распространялись, по крайней мере в Балтийском палеобассейне, явно в более глубоководных условиях, чем верхнеордовикские. Они встречаются здесь в глинистых и детритовых мергелях склоновой фации вместе с брахиоподами сообществ Clorinda (в юуруском горизонте) и Dicoelosia-Skenidioides (в яаниском горизонте; см. Кальо, Рубель, 1982, рис. 2.2, 2.5).

Сообщества и ассоциации верхнеордовикских брахиопод Прибалтики еще слабо изучены. Р. Мянниль $(1966$, рис. 44) выделил для биогермного комплекса поркуниского возраста Северной Прибалтики биофацию (биофациальную зону), названную по эндемичному роду 
брахиопод Ilmarinia. По площади распространения и частоте встречаемости среди брахиопод этого комплекса наиболее характерны представители родов Rafinesquina, Leptaena, Platystrophia, а также рода Streptis. Североприбалтийская фауна брахиопод поркуниского горизонта, несомненно, заслуживает ее выделения в качестве самостоятельной ассоциации. По мнению автора данной статьи, эту ассоциацию целесообразно называть по роду Streptis, который известен и за пределами Прибалтики, встречается довольно часто во всех трех пачках поркуниского горизонта, связанных с биогермами (в вохилайдской, сиугеской, тыревереской пачках) и который по характерной внешней скульптуре легко разпознаваемый даже по фрагментарному материалу.

Вне Прибалтики стратиграфически наиболее высокие ордовикские стрептисы известны в ирландском разрезе Килдэр, где они приурочены наиболее древней части горизонта Хирнант (Wright, 1968, Williams, 1972). При сопоставлении последнего с поркуниским горизонтом следует, что в Прибалтике могут быть представлены наиболее молодые ордовикские стрептисы. Но можно предполагать, что отмеченные выше ирландские и эстонские ордовикские представители рода Streptis более или менее одновозрастные. В таком случае можно сделать вывод об отсутствии некоторой части отложений позднехирнантиевого возраста в Северной Прибалтике, но которые в Средней Прибалтике могут представлять верхнюю половину т. н. далманитиновых слоев. Аналогичное можно сказать о сопоставлении поркуниских биогермов с верхней половиной органогенных построек известняка Буда в Швеции (Мянниль, 1966), которая по В. Яануссону (Јaanusson, 1982) соответствует только нижней половине горизонта Хирнант в Великобритании.

Автор благодарен старшим научным сотрудникам Л. Пылма, М. Рубелю и доктору геол.-минерал. наук Х. С. Розман за предоставленные материалы по стрептисам и за критические замечания.

Описанная коллекция хранится в Институте геологии АН ЭССР.

Семейство Triplesiidae Schuchert, 1913

Род Streptis Davidson, 1881

Streptis undifera (Schmidt, 1858)

Табл. I, фиг. $1-18$

Spirigerina? undifera: Schmidt, 1858, c. 212.

Streptis incompta: Ulrich, Cooper, 1936 , с. 345 , табл. 50 , фиг. $13,25-27$, 29 , 30, 33-35; Никифорова, 1960, табл. 26, фиг. 11-13.

Streptis undifera: Wright, 1965, табл. 1, фиг. $1-4$.

С и нтипы. Две брюшные и три спинные створки (Ulrich, Cooper, 1936, табл. 50, фиг. $13,25-27,29,30,33-35)$. Поркуниский горизонт $\left(\mathrm{F}_{\mathrm{II}}\right)$, Поркуни (Borkholm), Северная Эстония. Хранятся в Национальном музее США, Вашингтон.

Ди а гноз. Раковина двояковыпуклая с сильно выпуклой спинной створкой. Синус неглубокий, седло асимметричное, развитое на передней половине спинной створки. Основания для прикрепления ламелл нарастания (оторочек) представлены $3-8$ четкими постоянными уступами на поверхности створки. Расстояния между уступами $0,5-2,0$ мм. Ребристость четкая на уступах и на оторочках. В 3 мм от макушки на ширине 2 мм насчитывается 2-9 ребрышек.

Описание. Раковина средних для рода размеров, шириной до 11. мм, двояковыпукла с более выпуклой спинной створкой. Очертание от овального слегка вытянутого в ширину до субпентагонального. Соотношение длины брюшной $\left(x_{1}\right)$ и спинной $\left(x_{2}\right)$ створок к ширине 
$\left(x_{3}\right)$ соответственно 0,84 и 0,74 . Замочная линия прямая, почти вдвое короче ширины раковины, замочные углы округленно-тупые. Передняя комиссура сечкообразная.

Внешняя скульптура состоит из тонких концентрических струек и выдержанных по всей створке уступообразных валиков, оснований для ламелл наарастания, развитых в виде оторочек (шлейфов). Количество уступов варьирует от 3 до 8 , обычно 4 или 5 мм. Расстояния между вершинами уступов $0,5-2,0$, чаще всего $1,4-1,5$ мм. Ширина шлейфа достигает 2 мм у переднего края раковины, что составляет приблизительно одну треть длины створки без шлейфа. В отношении поверхности створки оторочки расположены под острым углом. Поверхность створок и шлейфов покрыта тонкой поперечной штриховкой (струйками), на 1 мм насчитывается около 15 струек. Радиальные ребрышки непостоянной толщины, низкие, в поперечном сечении округлые. Они появляются у первого, наиболее заднего уступа в количестве 15-20. В 3 мм от макушки спинной створки на ширине 2 мм насчитывается 4-9 ребрышек. Они едва заметны перед каждым уступом, их толщина увеличивается в сторону следующего уступа и оторочки. Увеличение числа ребрышек происходит между уступами путем вклинивания. У краев раковины число ребрышек доходит до 40 .

Брюшная створка умеренно выпуклая с асимметричным синусом, появляющимся на расстоянии около 2 мм от макушки. Макушка острая, треугольная, загнутая назад. Арея вогнута, высотой до 0,8 мм. Спинная створка сильно выпуклая, седло выражено слабо, в передней половине створки его ширину маркирует изогнутость концентрической скульптуры в сторону макушки. Макушка незаметная. Внутреннее строение прослеживается по одной створке. Кардиналий приподнят со дна створки. Брахиофоры развиты в виде маленьких треугольных пластин. Замочный отросток длинный $(1,8 \mathrm{mм})$, двулопастный с изогнутым стволом, раздвоенная часть отростка составляет половину его длины. Ветви отростка расположены под острым углом.

Размеры, мм:

$\begin{array}{llcccc}\text { Раковина } & & x_{1} & x_{2} & x_{3} & x_{4}^{*} \\ \text { Спннная створка } & \mathrm{Br} 4331 & 6,5 & 5,7 & 7,8 & 5,5 \\ \text { Спннная створка } & \mathrm{Br} 4333 & - & 3,7 & 5,0 & - \\ \text { Спинная створка } & \mathrm{Br} 4334 & - & 7,5 & 9,5 & 2,5 \\ \text { Брюшная створка } & \mathrm{Br} 4335 & - & 6,7 & 9,2 & 2,6 \\ \text { Брюшная створка } & \mathrm{Br} 4336 & 6,7 & - & 8,0 & - \\ \text { Спинная створка } & \mathrm{Br} 4338 & \mathbf{7 , 0} & - & 8,0 & \sim 2 \\ \text { Брюшная створка } & \mathrm{Br} 4339 & - & 6,5 & 9,0 & - \\ \text { Спинная створка } & \mathrm{Br} 4344 & \mathbf{7 , 3} & - & 8,5 & - \\ \text { Брюшная створка } & \mathrm{Br} 1552(2) & - & 6,0 & 8,7 & 3,0 \\ \end{array}$

* Толщина раковины.

С ра внен ие и з а ме ч ан и. Streptis undifera отличается от сходного с ним вида $S$. monilifera из верхнего ордовика Ирландии более грубой внешней скульптурой раковины, прежде всего меньшим количеством шлейфов, основания которых развиты в виде непрерывных уступов у первого вида. На спинной и брюшной створках $S$. undifera длиной около 5 мм и больше насчитывается $4-8$ уступов. У вида $S$. monilifera раковины таких же размеров вообще редки и их характеризует 7-12 уступов (Wright, 1960, рис. 3, табл. 3). Различия между отмеченными видами по радиальной скульптуре менее четкие: y $S$. undifera на расстоянии 3 мм от макушки на ширине 2 мм насчитывается 4-6 ребрышек в 11 случаях и $7-9$ ребрышек в 6 случаях, 
у S. monilifera - в 13 и 2 случаях соответственно. Описанный вид отличается от $S$. monilifera еще большей толщиной раковины, особенно более выпуклой спинной створкой, и, возможно, более загнутой назад макушкой брюшной створки. Оба верхнеордовикские виды отличаются от силурийских видов более грубой внешней скульптурой. Возможно, что эти различия обусловлены изменениями в среде обитания этих брахиопод: ордовикские виды с наиболее грубой и выразительной внешней скульптурой ( $S$. undifera, $S$. monilifera) распространялись в мелководных фациях, а силурийские виды с более хрупкой и тонкой скульптурой - в более глубоководных (S. altosinuata, S. grayii, S. glomerata).

Р асп постр анение. Верхний ордовик, вохилайдская $\left(\mathrm{F}_{\mathrm{II}} \mathrm{V}\right)$, сиугеская $\left(\mathrm{F}_{\Pi \mathrm{S}}\right)$ и тыревереская $\left(\mathrm{F}_{\mathrm{II}} \mathrm{T}\right)$ пачки поркуниского горизонта Северной Эстонии; горизонт $5 a$ в Норвегии (Wright, 1965).

Местонахождение (см. рис.). $\mathrm{F}_{I I} \mathrm{~V}$ : скв. Пухму, гл. 34,6 м 1 створка, гл. 34,5 м - 1 створка; $\mathrm{F}_{\mathrm{II}} \mathrm{S}$ : Поркуни - 29 створок; скв. № 192 (Водья, в окрестностях Пайде) - 1 створка; $\mathrm{F}_{\text {II }}$ Т: скв. № 188 (Пыхяка), гл. 61,5 м - 1 створка; Рёа-Якоби - 1 створка; валун в Рёа-Якоби -2 нецелых створки; валун в пос. Қянну (в окрестностях Варбола) - 1 раковина, 28 створок различной сохранности.

\section{Streptis altosinuata Holtedahl, 1916}

Табл. II, фнг. 11,12

Синонимику и типовые экземпляры см. по Коксу (Cocks, 1978 , c. 89$)$.

О п и с ан и е. В коллекции имеется одна брюшная створка ( $\mathrm{Br} 1846)$ из верхней части мергелей ыхнеской свиты юуруского горизонта $\left(\mathrm{G}_{1-2} \mathrm{O}\right)$ на глубине 311,0 м разреза скважины Абья.

Брюшная створка слабовыпуклая с асимметричным синусом. Очертание овальное, вытянутое в ширину, длина створки равна $3 / 4$ ее ширины. Замочная линия прямая, ее длина соответствует половине ширины створки. Арея апсаклинная, вогнутая в подмакушечной части, ее высота (0,6 мм) составляет $1 / 8$ длины арея. Дельтирий покрыт треугольным псевдодельтидием с четким высоким килевидным валиком. Форамен апикальный. Внешняя скульптура состоит из восьми концентрических низких узловатых уступов, первый из них на расстоянии 1,2 мм от макушки. Расстояние между уступами в срединной части створки $0,3-0,5$ мм. Радиальная скульптура развита слабо только на уступах.

Схема расноложения местонахождений видов из рода Streptis в Эстонии.

1 - обнажения или эрратическне валуны, 2 - скважнна, 3 - современная граннца распространения отложений поркуниского горизонта (по данным Л. Пылма).

Распространение $S$. undifera (cм. также Schmidt, 1858): 4 - обнажения Поркуни, Эрина, Роосна, Койги; 5 - Пурди; 6 - Сиуге; 7 - Хяркюла, Рёа-Якоби, Сели-Руссалу, Варбола; 8 - Руунавере; 9 Вохилайд, Хелтермаа; $10-$ Пухму; 11 - № 188 (Пыхяка), № 192 (Водья); S. alto-

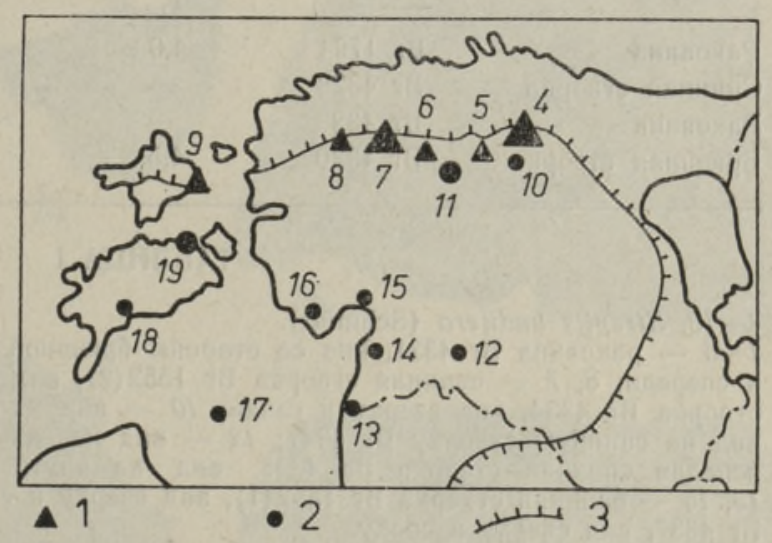
sinuata: 12 - Абья; S. grayii: 13 - Икла; 14 - Ристикюла; 15 - Пярну; 16 Селисте; 17 - Рухну; 18 - Қингисепп; 19 - Қыйнасту. 
С равнение. Описанная створка отличается от описанных выше экземпляров $S$. undifera менее развитой радиальной скульптурой, более низкими и узловатыми уступами и меньшим расстоянием между последними. По характеру внешней скульптуры створка отнесена к виду S. altosinuata (Wright, 1960), а не к S. monilifera (Рубель, Мустейкис, Попов, 1984).

Р аспростр анен и е. Нижняя часть нижнего лландовери, горизонт $6 a-b$ в районе Осло, Норвегия (Holtedahl, 1916); формация Woodland (Rhuddanian), Гёрван (Cocks, 1982$)$; юуруский горизонт $\left(\mathrm{G}_{1-2}\right)$ в Прибалтике. Верхняя часть нижнего лландовери, $\mathrm{A}_{3-4}$; Мейфод, Монтгомери, Уэльс (Temple, 1970).

\section{Streptis grayii (Davidson, 1848) \\ Табл. II, фиг. 13-24}

Синонимику и лектотип см. по Бассету (Bassett, 1972, с. 74). Оп и сание. Раковина небольших размеров, неравнодвояковыпуклая с более выпуклой спинной створкой. Очертание овальное, вытянутое в ширину, длина спинной створки составляет 3/4 ее ширины. Замочная линия прямая, длиной $2 / 5-3 / 5$ ширины раковины. На обеих створках имеется асимметричный синус, один борт которого высокий крутой, другой низкий с плавным переходом на боковую часть створки. Синус начинается 0,5-1,0 мм от макушки. У передней комиссуры, имеющей сечкообразную форму, глубина синуса у двух раковин составляет 3/5 толщины раковины. Макушка брюшной створки небольшая с апикальным фораменом. Арея слабо апсаклинная, вогнутая. Дельтирий покрыт треугольным псевдодельтидием с килеобразным валиком в середине.

Спинная створка сильно выпуклая, с наиболее высокой точкой около середины. Арея не развита. Кардиналий выделяется вентрально, приподнят со дна створки. Брахиофоры отгибаются латерально, их основания разграничивают зубные ямки. Замочный отросток массивный раздвоенный, выдается за замочный край. Со стороны нототирия основание отростка покрыто «воротничком» вторичного раковинного вещества. Аддукторное поле узкое, задние аддукторы значительно меньше передних.

Внешняя скульптура состоит из концентрической тонкой штриховки и низких валиков (уступов). Число последних достигает 17, обыкновенно их 7 или 8. Уступы появляются на расстоянии $0,7-1,0$ мм от макушки, а расстояние между ними составляет $0,3-0,5$ мм.

Размеры, мм:

\begin{tabular}{lccccc} 
Раковнна & & $x_{1}$ & $x_{2}$ & $x_{3}$ & $x_{4}$ \\
Спинная створка & $\mathrm{Br} 1794$ & 4,0 & 3,8 & 5,7 & 3,4 \\
Раковнна & $\mathrm{Br} 4328$ & - & 3,8 & 5,7 & - \\
Брюшная створка & $\mathrm{Br} 4329$ & - & $\sim 5$ & - & 4,2 \\
\hline
\end{tabular}

\section{ТАБЛИЦА I}

1-18. Streptis undifera (Schmidt).

1-5 - раковина $\mathrm{Br} 4331$, вид со стороны брюшной и спинной створок, сбоку, сзади и спереди; 6,7 - спинная створка $\mathrm{Br} 1552(2)$, вид сверху и сбоку; 8,9 - спинная створка $\mathrm{Br} 4334$, внд сверху и сзади; 10 - вид на спинную створку $\mathrm{Br} 4335 ; 11$ вид на спннную створку $\mathrm{Br} 4347 ; 12$ - вид на спинную створку $\mathrm{Br} 4333 ; 13,14-$ нецелая спинная створка $\mathrm{Br} 4345$, вид на внутреннюю поверхность, вид сбоку; 15,16 - спинная створка $\mathrm{Br} 1552(1)$, вид сверху и сзади; $17,18-$ брюшная створка $\mathrm{Br} 4337$, внд сверху и сбоку.

$1-5,8-10,12,17,18$ - валун в пос. Кянну, в окрестностях Варбола, $\mathrm{F}_{\text {II T }}$ (сборы Л. Пылма); 6, 7, 15,16-Поркуни, $\mathrm{F}_{\mathrm{II}} \mathrm{S}$ (коллекция музея ИГ); 11, 13, 14 Поркуни, FIIS (сборы автора). (Увел. ×5.) 

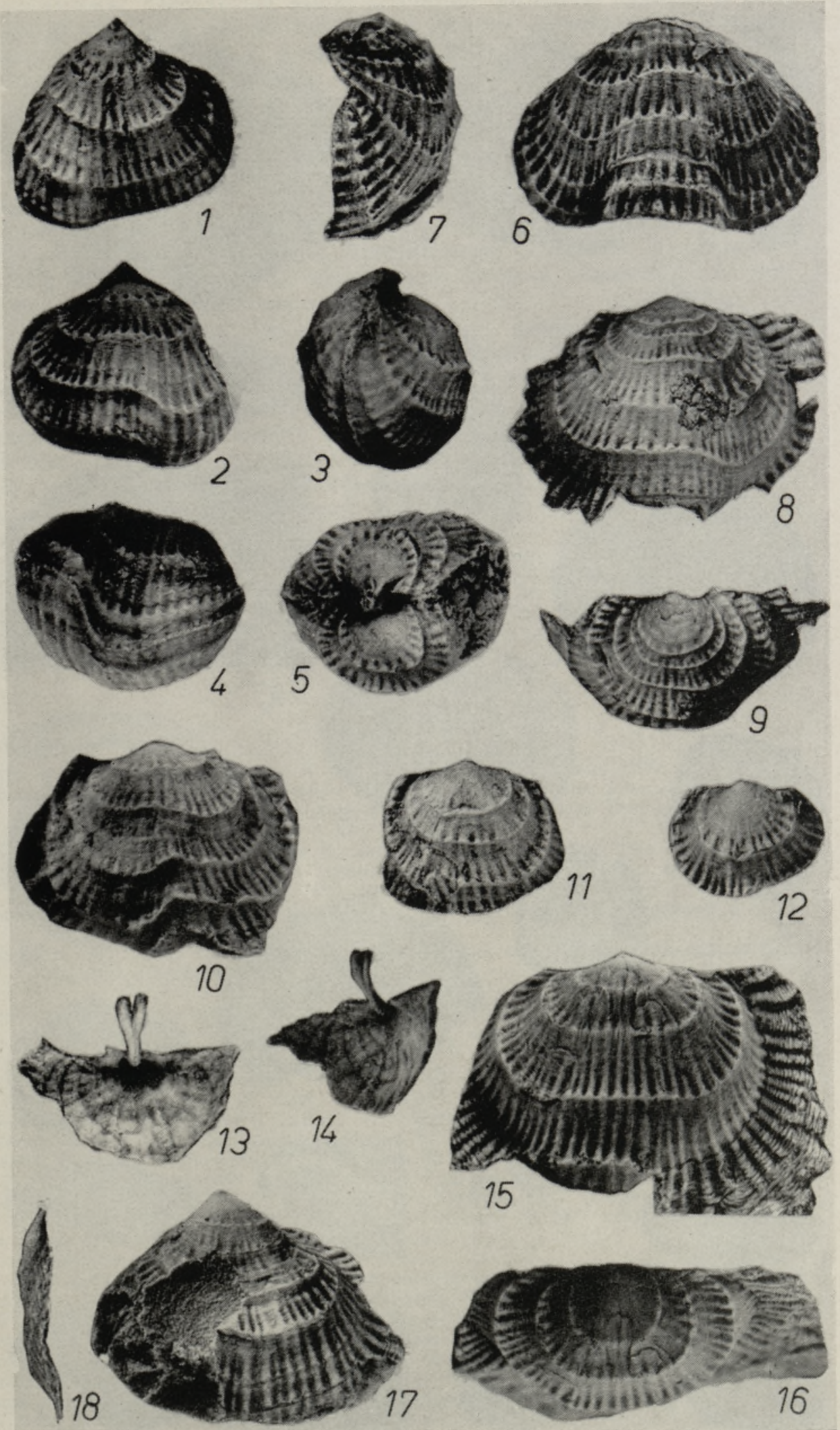

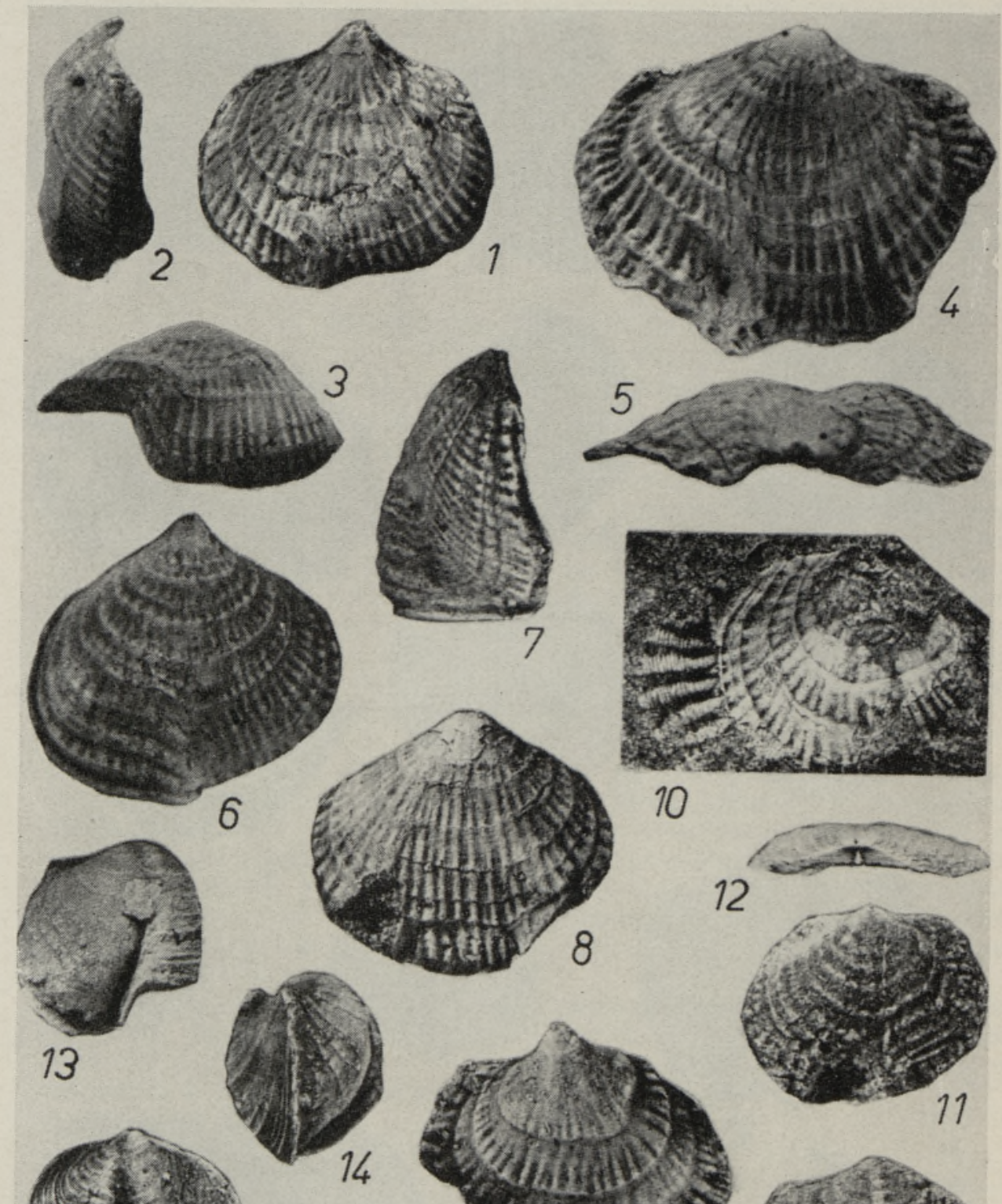
10
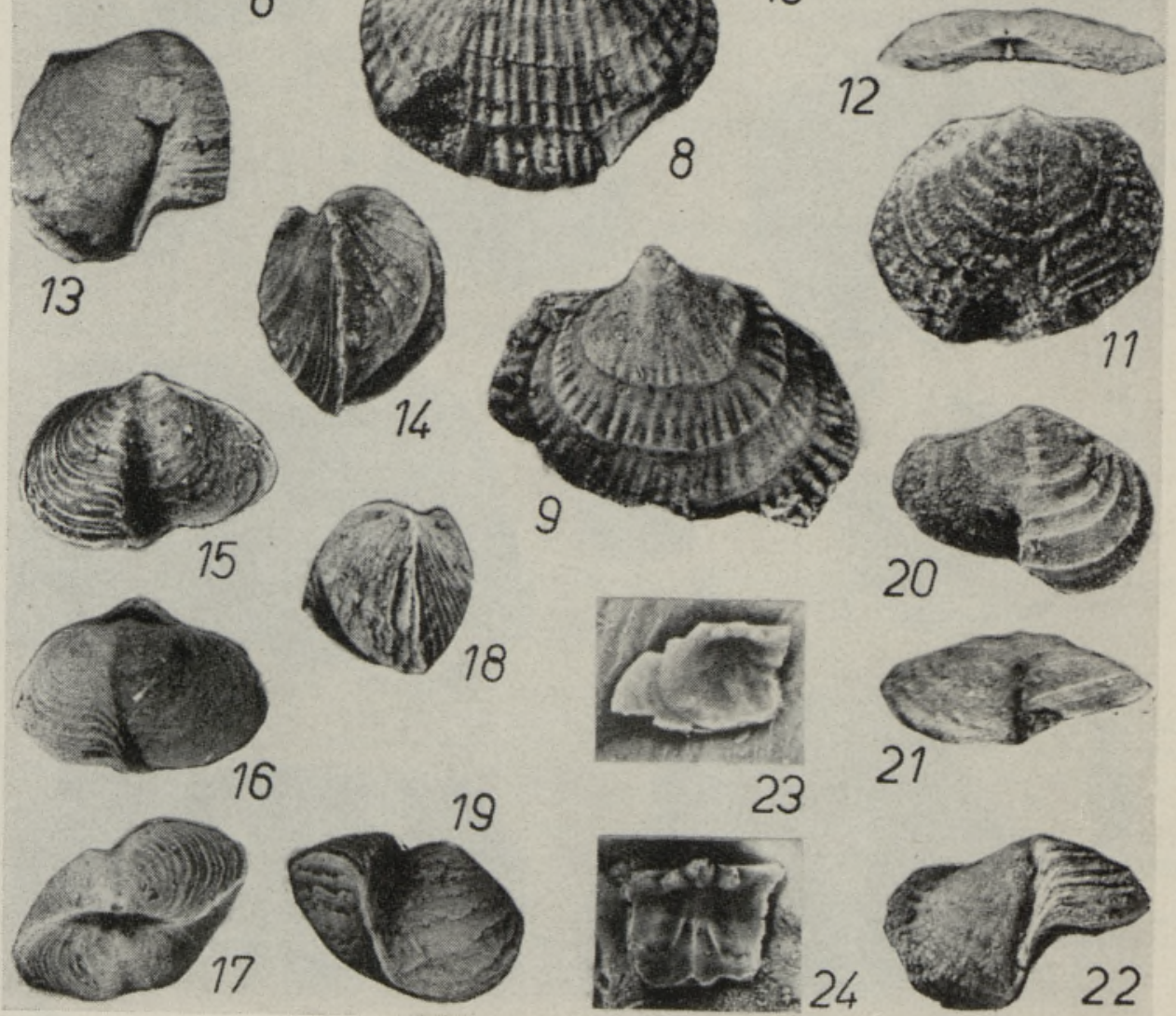
С равнение. Описанный выше эстонский материал отнесен к виду S. grayii прежде всего по признакам формы раковины и внешней скульптуры. Эстонские $S$. grayii, как и подольские (Цегельнюк, 1976, c. 59), по размерам раковины являются переходными между экземплярами этого же вида из Великобритании и S. glomerata (Ulrich, Cooper, 1936) из венлока Северной Америки. Следует отметить, что S. glomerata описан менее детально чем $S$. grayii и трудно обсуждать об их различиях, возможно, отчасти обусловленных фациальными условиями.

Единственная створка S. altosinuata из юуруского горизонта отличается от описанных $S$. grayii относительно бо́льшими размерами и слабо развитой радиальной скульптурой, давшей узловатый вид концентрическим валикам (уступам).

Р аспр остр анение. Верхний лландовери, формация Вик в Норвегии (Cocks, Baarli, 1982), венлок в Великобритании и на о-ве Готланд (Bassett, 1972), яаниский горизонт в Әстонии, венлок в Литве (по неопубликованным материалам П. Мустейкиса). В отмеченных ниже разрезах границы яаниского горизонта приняты по А. Аалоэ (1970) и Д. Кальо, М. Рубелю (1982).

Ме стон ахожден и е. Скв. Кингисепп, гл. 163,0-163,1 м (1 нецелая раковина); скв. Селисте, гл. 149,5 м (1 створка); скв. Пярну, гл. 109,6 м (1 нецелая створка); гл. 112,0 м (1 раковина), гл. 120,43 м (1 нецелая створка), гл. 122,22 м (2 нецелые створки); скв. Ристикюла, гл. 157,7 м (1 створка); скв. Икла, гл. $276,0-276,1$ м (2 нецелые створки), гл. $277,0-277,1$ м (1 нецелая створка), гл. $278,0-278,1$ м (1 нецелая раковина), гл. 278,8-278,9 м (1 створка); скв. Кыйнасту, гл. 34,5 м (1 створка); скв. Рухну, гл. 402,6 м (1 раковина).

\section{ЛИТЕ Р А Т У Р А}

Аалоэ А. Яаниский горнзонт. - В кн.: Снлур Эстонин. Таллин, 1970, 243-250.

Кальо Д., Рубель М. Связь сообществ брахнопод с фациальной зональностью (снлур Прибалтики). - В кн.: Сообщества и биозоны в силуре Прибалтикн. Таллин, $1982,11-34$.

Мянниль P. М. История развития Балтийского бассейна в ордовике. Таллин, 1966. Никифорова О. И. Надсемейство Triplesiacea. - В кн.: Основы палеонтологин. Мшанки, брахноподы. М., 1960, 205-206.

Пылма Л. Сравнительная литология карбонатных пород ордовика Северной и Средней Прибалтики. Таллин, 1982.

Рубель М., Мустейкис П., Попов Л. Систематический список брахиопод силура Прибалтикн. (Препрннт). Таллнн, 1984.

\section{ТАБЛИЦА II}

1-10. Streptis undifera (Schmidt).

1-3 - брюшная створка $\mathrm{Br} 4338$, вид сверху, сбоку и спереди; 4, 5- брюшная створка $\mathrm{Br} 4332$, вид сверху и сзади; 6,7 - брюшная створка $\mathrm{Br} 1552(5)$, вид сверху и сбоку; 8,9 - виды на брюшные створки $\mathrm{Br} 4344$ и $\mathrm{Br} 4336 ; 10$ - вид на внутреннюю поверхность нецелой спинной створки $\mathrm{Br} 4346$.

$1-3,8-10$ (сборы автора); 6, 7 - Поркуни, $\mathrm{F}_{\mathrm{II}} \mathrm{S}$ (коллекция музея ИГ АН ЭССР): $4,5,9$ - валун в пос. Кянну, в окрестностях Варбола, $\mathrm{F}_{\mathrm{II}} \mathrm{T}$ (сборы Л. Пылма).

11, 12. Streptis altosinuata Holtedahl. Спинная створка $\mathrm{Br} 11846$, вид сверху и сзади; скв. Абъя, гл. 311,0 м, $\mathrm{G}_{1-2} \mathrm{O}$ (сборы М. Рубеля).

13-24. Streptis grayii (Davidson).

13, 14 - нешелая раковина $\mathrm{Br} 4329$, вид со стороны спинной створки и сбоку, скв. Икла (гл. 287,0-287,1 м); $15-19$ - раковина $\mathrm{Br} 1794$, вид со стороны брюшной и спинной створок, сбоку, спереди и сзади, скв. Рухну (гл. 402,6 м); 20, 21 брюшная створка $\mathrm{Br} 4330$, внд сверху и сзади, скв. Рнстикюла (гл. 157,7 м); 22 брюшная створка $\mathrm{Br} 4328$, скв. Кыйнасту (гл. 34,5 м); 23 - нецелая спинная створка $\mathrm{Br} 1847$, вид на внутреннее строение, скв. Пярну (гл. 122,22 м); $24-$ нецелая спинная створка $\mathrm{Br} 1848$, вид на внутреннее строение, скв. Икла (гл. 277,0277,1 м), $\mathrm{J}_{1}$ (сборы М. Рубеля). (Увел, Х5.) 
Цегельнюк П. Д. Брахиоподы и стратиграфия нижнего палеозоя Волыно-Подолии. Киев, 1976.

Bassett, M. G. The articulate brachiopods from the Wenlock Series of the Welsh Borderland and South Wales. Part 2. - Palaeontogr. Soc. (Monogr.), N 532, 1972, $27-78$.

Brenchley, $P$. J., Cullen, $B$. The environmental distribution of associations belonging to the Hirnantia fauna - evidence from North Wales and Norway. - In: Bruton, D. L: (ed.). Aspects of the Ordovician System. Paleont. Contr. Univ. Oslo, $1984, \mathrm{~N} 295,113-125$.

Brenchley, P. J., Cocks, L. R. M. Ecological association in a regressive sequence the latest Ordovician of the Oslo-Asker District, Norway. - Palaeont., 1982, 25. N 4, 783-815.

Cocks, L. R. M. A review of British Lower Palaeozoic brachiopods including a synoptic revision of Davidson's Monograph. - Palaeontogr. Soc. (Monogr.), N 549, 1978.

Cocks, L. R. M., Baarli B. G. Late Llandovery brachiopods from the Oslo Region. Paleont. Contr. Univ. Oslo, 1982, N 278, 79-90.

Holtedahl, $O$. The Strophomenidae of the Kristiania Region. Kristiania, 1916.

Jaanusson, $V$. Introduction to the Ordovician of Sweden. - In: Field Excursion Guide. IV Int. Symp. Ordovician System. Paleont. Contr. Univ. Oslo, 1982, N 279, $1-9$.

Mitchell, W. I. The Ordovician Brachiopoda from Pomeroy, Co. Tyrone. - Palaeontogr. Soc. (Monogr.), N 545, 1977.

Schmidt, Fr. Untersuchungen über die Silurische Formation von Estland, Nord-Livland und Oesel. - Archiv Naturk. Liv., Ehst.- u. Kurlands, 1858. Ser. I. N 2.

Temple, J. T. The Lower Llandovery brachiopods and trilobites from Ffridd Mathrafal, near Meifod, Montgomeryshire. - Palaeontogr. Soc. (Monogr.). N 527. 1970.

Ulrich, E. O., Cooper, G. A. New Silurian brachiopods of the family Triplesiidae. J. Paleont., 1936, 10, N 5, 331-347.

Williams, A. Ireland. - In: A correlation of Ordovician rocks in the British Isles. Geol. Soc. Special Report. 1972, N 3, 53-59.

Wright, A. D. The species Streptis monilifera (M'Coy). - Norsk Geol. Tiddskr., 1960, 40, N $3-4,259-276$.

Wright, A. D. The fauna of the Portrane Limestone. II. - Bull. Brit. Mus. (Nat. His.), Geol., 1964, 9. N 6, 160-256.

Wright, A. D. The occurrence of Streptis (Brachiopoda) in the Ordovician of the Inner Oslo Fjord. - Norsk Geol. Tiddskr., 1965, 45, N 4, 473-480.

Wright, A. D. A westward extension of the upper Ashgillian Hirnantia fauna. - Lethaia, $1968,1, \mathrm{~N} 4,352-367$.

\author{
Ннститит геологии \\ Академии наук Эстонской ССР
}

Поступила в редакцию

14/I 1985

\title{
Linda HINTS
}

\section{PEREKOND STREPTIS (TRIPLESIIDAE, BRACHIOPODA) EESTI ORDOVIITSIUMIST JA SILURIST}

Artiklis on kirjeldatud perekonna Streptis kolm Eesti ordoviitsiumis ja siluris esinevat liiki: S. undifera porkuni. S. altosinuata juuru ja $S$. grayii jaani lademest. On pööratud tähelepanu nende liikide leviku ja karbi välisskulptuuri võimalikule sõltuvusele fatsiaalsetest tingimustest. Peetakse otstarbekaks välja eraldada brahhiopoodide assotsiatsioon nominaalse perekonnaga Streptis. Assotsiatsioon iseloomustab porkuni ea madalikufaatsiese biohermikompleksi. Streptis'e liikide levik Iirimaa ja Eesti ordoviitsiumis viitab võimalusele, et Streptis-assotsiatsiooni sisaldavad kihid Põhja-Eestis vastavad vanuseliselt Dalmanitina-kihtide alumisele poolele Kesk-Baltikumis ja seega ka Hirnantia lademe alumisele poolele Inglise stratigraafilises skeemis.

\section{Linda HINTS}

\section{GENUS STREPTIS (TRIPLESIIDAE, BRACHIOPODA) FROM THE ORDOVICIAN AND SILURIAN OF ESTONIA}

The Estonian collection of the genus Streptis - S. undifera from the Porkuni $\left(\mathrm{F}_{\mathrm{II}}\right)$, $S$. altosinuata from the Juuru $\left(\mathrm{G}_{1-2}\right)$ and $S$. grayii from the Jaani Stage $\left(\mathrm{J}_{1}\right)-$ is described. It is proposed that the Ordovician species of Streptis with a strong external sculpture tends to colonize shallower water environments than the Silurian ones, with a more delicate and frail sculpture. The Late Ordovician brachiopod fauna from the reefs and related North-Estonian sediments is considered the Streptis Association. According to the known distribution of $S$. undifera and $S$. monilifera, some parts of Late Hirnantian sediments may be missing in North Estonia. 